\title{
Traditional Versus Online Learning in Institutions of Higher Education: Minority Business Students' Perceptions
}

\author{
Falih M. Alsaaty ${ }^{1}$, Ella Carter $^{1}$, David Abrahams ${ }^{1} \&$ Faleh Alshameri $^{1}$ \\ ${ }^{1}$ College of Business, Bowie State University, Bowie, MD, USA \\ Correspondence: Ella Carter, Bowie State University, College of Business, Department of Management, Marketing \\ and Public Administration, 14000 Jericho Park Rd. Bowie, MD 20715, USA
}

Received: April 20, 2016

Accepted: May 17, 2016

Online Published: May 20, 2016

doi:10.5430/bmr.v5n2p31

URL: http://dx.doi.org/10.5430/bmr.v5n2p31

\begin{abstract}
For decades, scholars have debated which mode of education is superior. Some argue that online is superior and others argue that online is less effective than traditional face-to-face courses. Still others suggest that the hybrid mode (e.g., online blended with face-to-face lectures) is the most desired and productive content delivery method for students. However, students' perceptions towards online learning as compared to traditional face-to-face learning have largely been overlooked. This paper intends to fill this void in the literature and explore minority students' perceptions towards online learning versus traditional face-to-face modes of education in higher education.
\end{abstract}

Keywords: Online education, Minority students, Traditional instruction, Course delivery preferences

\section{Introduction}

Institutions of higher education in the United States in particular, and elsewhere around the world in general, have gradually been adopting a strategy of online learning delivery in lieu of, or in combination with, the traditional in-class, on-campus education. According to a 2011 report, over 6.1 million students were taking at least one online course in 2010 , with $31 \%$ of all students in higher education taking at least one online course. In a more recent report (Allen and Seamans, 2013), the number had increased by 570,000 students for a total of million students taking at least one online course. The report further states that while the number of students taking at least one online course is at its highest level with a growth rate of $9.3 \%$ and shows no evidence of the trend slowing in the future. This trend has left many to question what factors are driving this shift and how this shift will ultimately affect institutions across the country.

The shift in strategy for educational delivery has been driven by external forces beyond the influence of the institutions as well as by their internal dynamics. According to Deming et al (2016), the growth in for-profit education and the increased number of public universities in the online sector has had a significant impact on course delivery methods. In addition, the intense competition among these institutions seeking greater enrollment has become another important factor for strategy determination in academic planning. For example, the number of institutions that offer very similar degree programs is strikingly high. According to the National Center for Education Statistics (2015), the number of degree granting institutions in the United States was 4,703 in 2011. Since that time a number of institutions have faced numerous challenges, including budget cuts, declining enrollment and the emergence of a variety of new educational opportunities for students. Giroux (2015) addresses some of the issues and even states, "the future of higher education is in a state of crisis and many of the challenges include budget cuts, diminishing quality, the downsizing of faculty, and the revamping of the curriculum to fit the needs of the market." The unfavorable environment of the higher education institutions was also addressed in the December 2012 issue of The Economist which indicated that there was concern in the United States about rising tuition fees, increasing student debt burden, dwindling the institutions' financial return, and shrinking educational benefits.

The economic slowdown, the crash of the stock market, the meltdown of the real estate market, and high unemployment levels have all contributed over the past decade to stagnating or declining enrollment in many colleges and universities around the country. On the other hand, the institutions of higher education have steadily been facing mounting costs for new technologies, campus renovation, employees' compensation, and the like while, at the same time, they have experienced severe budgetary constraints as a result of dwindling revenue and 
endowment. Adding to these impediments is the threat to many institutions posed by the spread of massive open online courses (MOOCs), that is, the free online college courses for the public around the world.

Consequently, the influence of these external and internal forces have made it imperative for the great majority of the institutions to rethink their traditional educational strategy by "going online" and adopting technological innovations that help accommodate greater enrollment through a more manageable cost structure. It is assumed in this paper that the more favorable students' perceptions towards online learning, the greater the tendency of potential learners to enroll in programs of study. The offering of online courses/programs coupled with increased enrollment could help reduce the overall cost of education to many institutions. Numerous studies have been published (Brown, 2016; Pai, 2013; Summers, 2005; Clark, 2001) that compare traditional and online programs in majority institutions. Additional research (Fedynich, 2015; John et al, 2015) has also examined students' perceptions about online education. However, little research has been done to investigate students' perceptions of traditional versus online education in a minority-serving institution.

The purpose of this paper is to investigate students' perceptions towards online learning versus traditional face-to-face mode of education in a minority-serving institution of higher education. Graduate and undergraduate students enrolled in a Historically Black College and University (HBCU) were selected during the fall of 2014 as the focus of the study.

\section{Literature Review}

\subsection{Brief Historical Perspectives}

As the movement of online learning continues to expand in developed and developing countries often fueled by technology and increasing demand for higher enrollment, among other things, one might ask: What is the history of the movement? Where did the movement originate? These and other questions need to be addressed to further understand the ramifications of the movement, especially in terms of its social and financial costs and benefits to the nation.

The history of online learning is particularly fascinating because it demonstrates the contributions of individuals and institutions to the advancement of education and the sharing of knowledge and skills on a global scale. As we briefly review the historical development of this subject, it is important to indicate that many authors (e.g., Ferriman, 2013; Schlosser et al, 2009; Moore, 1990; Keegan, 1980) use the terms "distance learning", "distance education", "online learning", and "online education" interchangeably, as is the case in this paper.

According to Pappas (2013), the term distance education was first used in the United States in 1892 in a pamphlet of the University of Wisconsin-Madison. The roots of the modern day Internet-based online learning in the United States go back to the paper-based correspondence study in Boston in 1728 when Caleb Phillips advertised a correspondence course in the Boston Gazette newspaper (Ferriman, 2013). In the 1800's, access to higher education was very limited because of geographic distance between potential learners and educational institutions until 1892 when Pennsylvania State University introduced a correspondence study program (Banas and Emory, 1998).

According to Miller (2014), the University of Chicago became the first institution of higher education to broadcast courses over the radio in 1922. Three decades later, in 1953, the University of Huston offered the first televised college classes. The transition from the "old" mode of education to the modern version of online learning took about four more decades and was fueled by the U.S. Department of Defense's Arpanet in 1969 and later the Internet. Published reports show that the University of Phoenix was established in 1989 to become the first privately owned academic institution to offer degree programs via synchronous online mode of delivery.

\subsection{Online and Traditional Courses Defined}

Online courses are typically defined courses where at least $80 \%$ of the content is delivered online without face-to-face meetings. Face-to-face instruction (F2F) is defined as a course where all content is delivered only in a traditional face-to-face setting. In addition to online and face-to-face learning courses, there are hybrid courses, which combine the benefits of face-to-face with the technology often used in online courses. According to the authors, $30-79 \%$ of the course is delivered online. Lastly, a fourth type of course exists which is referred to as the web-facilitated course, where $1-29 \%$ of the course is delivered online. Although this type of course is actually a face-to-face course, it uses web-based technology to supplement the face-to-face instruction provided to students (Allen and Seamans, 2011).

Given the variety of options available to students, how do the online courses compare to face-to-face courses? Are the learning outcomes the same or are online courses perceived as less or more rigorous than traditional face-to-face 
courses? These are just some of the many questions educators and administrators must answer. Numerous empirical studies have compared traditional face-to-face and online course delivery at a public, private and for-profit institutions, While there is a significant body of research (Farmakis and Kaulbach (2013); Katy and Anderson (2006); Pai (2013) to support that there is little change in the perception of face-to-face when compared online, much of the research focuses on majority institutions.

Several studies (Allen and Seaman (2013) and Nazarlou, (2013) discuss the perceptions of academic leaders and students in regard to online courses versus face to face classes. According to Allen and Seaman online courses were perceived to be inferior to face-to-face courses. Today the proportion of leaders with that negative perception had declined from approximately $40 \%$ in 2003 to $23 \%$ in 2012. In two studies, (Summer et al, 2005; and Kartha, 2006) student satisfaction was lower than students in traditional face-to-face courses.

However, proponents of online education (Bernard et al, 2004; Means et al, 2009 and Farmakis and Kaulbach (2013) have found little difference between the learning outcomes of the two learning formats. Although student perceptions of business courses in online versus face-to-face classes have been previously studied, the literature lacks information on minority student perceptions about online versus traditional learning.

Scholarly contributions to the analysis of the effectiveness of online education versus the traditional face-to-face approach could be classified into four schools of thought as shown below:

1. The sameness of online and traditional modes of learning, that is, the two modes are equally effective from the educational standpoint;

2. The superiority of the online mode relative to the face-to-face mode;

3. The superiority of the face-to-face mode relative to the online mode; and

4. The superiority of the hybrid education, that is, face-to-face lectures blended with an appropriate level of online learning.

Numerous authors (Dendir, 2016; Cavanaugh, 2015; Shotwell, 2015; Haughton, 2015; Oliver (2000), for example, have discussed different approaches to evaluating students' performance in an online small business management courses. According to Oliver (2000), these approaches include the formative, summative, illuminative, integrative, and quality assurance methods. More recently, various authors (Brown, 2016; Neuhauser 2010; Murdock et al 2012; Pai, 2013) have concluded that the performance of the online (distance) students was very similar to that of the on-campus face-to-face students. Katy and Anderson (2006) compared the performance of students enrolled in an online small business management course with the same course that was offered in a traditional, face-to-face mode. The authors found out that distance-learning students performed as well as those who were enrolled in a traditional mode.

Moreover, DiRienzo and Lilly (2014) compared students' learning outcomes on both "basic" and "complex" assignments for the same undergraduate business course using two different delivery methods: traditional and online. The authors pointed out that the delivery method had no significant difference in student learning outcomes. Similarly, Farmakis and Kaulbach (2013) found that well-structured online courses could lead to identical level of quality as traditional courses. Likewise, Murdock, Williams, Becker, Bruce, and Young (2012) investigated skills acquisition of students enrolled in face-to-face and online counseling course. The authors decided that online education could be as effective as traditional classroom teaching. Similarly, Pai (2013) and Neuhauser (2010) declared that there were no significant differences in learning outcomes between traditional and online learning even when gender and differences in learning styles were considered.

The discussions about the advantages and disadvantages of online learning versus traditional mode of education have been based on a variety of parameters. Harasim (1989) and Talebain et al (2014) indicated that face-to-face education is time and place dependent, while the online mode represents an augmented environment that allows individual users to exercise control over time, pace, place, and the interaction with instructors as well as other participants. Tseng and Chu (2010) studied the relationship between learning modes and outcomes in teaching economics courses. The authors found out that the online platform is crucial for facilitating better learning performance and, thus, it was superior to the traditional mode of education.

Furthermore, McCarty and Carter (2013) investigated students' performance in introductory microeconomics courses. They discovered that the average final grades in the online classes were slightly higher than the average grades for the face-to-face classes. Sauers and Walker (2004) examined the difference between traditional education and hybrid 
mode of teaching for business communications courses. They concluded that online courses could provide the best platform type of course delivery for certain students and certain courses.

Moreover, Kartha (2006) compared the effectiveness of teaching instructions in an undergraduate business statistics course taught both in traditional mode as well as online. The author pointed out that the students who were enrolled in the online course were significantly less satisfied with the course, and that they expressed their preferences for the traditional approach to learning. In another study Cao (2011) examined MBA students' course satisfaction and found that the students were less satisfied with online courses as compared to traditional face-to-face courses.

It should be noted that the factors that shape the effectiveness of online and traditional modes of education are many and often unpredictable. For instance, in a study about the MBA students' attitudes towards online learning, Kim, Liu, and Bonk (2005) indicated that virtual teaming among students was a key influencing factor in their online educational experience. In another study, Chou (2012) mentioned that there is a strong relationship between students' self-directed learning ability and their online learning performance.

Similarly, Hatcher, Henson, and LaRosa (2013) declared that the mode of instructions was the least important predictor of students' performance. What matters, according to the authors was students' grade point average (GPA). Cowden and Sze (2012) suggested that innovative instructors have helped design online courses that meet expected educational outcomes by assisting students to learn more with less exhaustive assignments and course work.

Moreover, the literature (Porter, 2015; Fedynich 2014; Shotwell, 2013;) has also shown that the effectiveness and advantage of online learning relative to traditional face-to-face lectures are influenced by a host of factors including, but not limited to, students' knowledge base of course materials and their technical capabilities to navigate throughout the online course, course design complexity as well as the degree of difficulty of course assignments and time intensity. Additional factors have also been shown to affect students' perceptions of online versus face-to-face courses. These include the nature of course communication (i.e., synchronous or asynchronous) and its frequency between the instructor and students and student academic course load. According to Bhuasiri et al (2012), curriculum design, technology infrastructure and course quality were additional factors to consider, especially in developing countries.

Lastly, it is also important to note that an October 2013 Gallup poll (Saad, Busteed, and Ogisi, 2013) regarding online education in the United States revealed that online education was positively perceived because it offers flexibility and a wide range of courses at reasonable costs. However, it was negatively perceived because it involves less qualified instructors and less demanding testing. Additionally, employers' perceived online learning with less confidence as compared to the traditional face-to-face learning mode of instruction.

\section{Methodology}

The objective of this descriptive research project is to identify and describe business students attending an historical black college and university (HBCU) perceptions of traditional versus online courses. More specifically the objective is to better understand the issues and curriculum challenges that need to be addressed in order to effectively provide quality online instruction to this population of students.

Colleges and universities all over the United States are faced with the growing pressure to include online teaching as part of their educational curriculum because online education is the fastest growing segment of higher education (Deming, Goldin, \& Katz, 2012 and Toven-Lindsey, 2015). HBCU's are no different than the predominantly white institutions (PWI) when it comes to the ever-increasing demand to include online instruction as part of the educational curriculum.

\subsection{Descriptive Research Study}

Descriptive research was chosen as a methodological approach for this study because it enables researchers to describe existing conditions without analyzing relationships among variables within the condition. According to Toven-Lindsey (2015), descriptive studies can answer questions, for example, "what is" or "what was" versus research experiments which characteristically answer the question "why" or "how." The advantage to this approach is that descriptive statistical data analysis enables researchers to meaningfully describe data using numeric indices or in graphic form.

Maxwell (2012) states that descriptive research is conclusive as opposed to exploratory in nature. In essence, this means descriptive research gathers quantifiable information in the form of closed-ended questions, which limits its ability to provide unique insights. However, when used properly organization can better define and measure the significance of issues impacting their respondents and the population they represent. In the case of this study, the 
researchers are interested in understanding not just the degree in which online classes are preferred but the degree of difficulty students perceived in online versus traditional courses.

The other reason for utilizing descriptive research is that this study is driven by applied research. Descriptive research according to Maxwell (2012) is a good tool to utilize for applied research; it enables the researcher to identify exactly what they are trying to discover in order to make educated decisions on the issues facing an organization. The analysis of the descriptive statistical data from this research will provide a conceptual framework to better address the issues of online instruction in order to effectively improve online instruction offered to this population of students.

The research instrument for this study was an online questionnaire, which consisted of 30 questions designed to elicit information about students' demographics such as age, gender, and study discipline during fall 2014. The questionnaire was also intended to learn about students' experience with online learning and face-to-face education, skills gained, difficulties encountered, and their perceptions (i.e., opinions) about the two platforms of study. The SPSS software was used to analyze the data.

\subsection{Sample}

Convenience sampling was used for the study. The sample in this study included 147 graduate and undergraduate students taking business courses during the Fall 2014 semester. This group included African-American, Hispanic/Latino and Middle Eastern students. Students were not given any monetary compensation for participation.

\section{Results}

The majority of the participants $(52.4 \%)$ in this survey were graduate students, female (57.8\%), in the age group between 18 and 30 years old (77.5\%), and employed either full time or part time (73.5\%). The data further indicated that respondents had previously enrolled in at least one online course. On the basis of available information, it could be argued that the perception expressed by the participants about online versus face-to-face learning was dependable, informative, and valuable.

When students were asked about their students' perceptions regarding the ease or difficulty of online lecture materials, course assignments, and online navigation, $30.2 \%$ of the students surveyed reported that they found the online lecture material satisfactory or easy to understand, while over $69.8 \%$ of students found the lecture material either difficult or very difficult to understand. In addition, $36.6 \%$ of respondents felt that online assignments were satisfactory or easily understood, while $63.4 \%$ of respondents found the online assignments difficult or very difficult. Similarly, $91.4 \%$ of the respondents reported that the degree of intuition required to navigate course online was either average or easy to find. The findings further indicate students' perceptions about the material are viewed as being rigorous even despite the ease of the navigation. No comparative analysis was done between the rigor between the face-to-face classes and online offerings. However, students perceived a difference between the amounts learned within the two modes even though course content was equivalent.

In academic environments, course organization and presentation are key factors that can either attract or distract students. Students seek clarity and relevance in studying materials presented to them. This seems to be the case for many of the courses at the institution in question. In this study, $74.3 \%$ of the participants were in agreement that the online courses they were enrolled in were well presented and well organized. Moreover, $86.3 \%$ of them reported that they use Blackboard, Angel or other online learning systems to network with other students and faculty members. The vast majority of the participants $(83.5 \%)$ also indicated that their experience with online learning was satisfactory or very satisfactory, a clear indication of acceptance of online learning as a powerful mode of education in institution of higher education.

On the other hand, $60.4 \%$ of the participants believe they have learned more in a face-to-face learning environment than in an online setting. Online learning is not always a seamless experience for students. Users encounter many problems including Internet interruption, system upgrade downtime, omitted or unstructured course materials, and the like. Respondents indicated that they encountered a host of problems including from lack of course instruction and/or organization to unreliable Internet connection as shown in Table 1. 
Table 1. Problems Encountered in Online Learning

\begin{tabular}{ll}
\hline Problem I encountered in online learning environment: & Percentage \\
\hline Lack of course instructions and/or organization & 24.5 \\
Difficult course materials & 19.0 \\
Difficulty in contacting the faculty concerned & 29.9 \\
Unreliable University Internet connection & 24.5 \\
All of the above & 3.4 \\
Other problems & 29.2 \\
\hline
\end{tabular}

One of the questions posed to students was designed to determine whether students who are enrolled in online courses learn new skills in additional to learning the subject matter of the course and if so, what are those skills might be. As the information in Table 2 shows, a slight majority (49.0\%) of the participants indicated that they learned new skills by enrolling in an online learning course. Only $30.6 \%$ of the respondents indicated that they did not learn new skills, while $20.4 \%$ of them pointed out that they were neutral about the subject matter (i.e., learning new skills). On the other hand, the participants said that they learned different skills such as course-related, Blackboard, and team formation skills. Based on the responses, it appears that online education provides participants with capabilities that extend beyond the core content that is embedded in courses and programs of study.

Table 2. Skills Learned in Online Courses

\begin{tabular}{ll}
\hline I acquired additional skills by enrolling in an online course (s) & Percentage \\
\hline Agree & 40.2 \\
Strongly agree & 8.8 \\
Disagree & 23.8 \\
Strongly disagree & 6.8 \\
Neutral & 20.4 \\
Total & $100 \%$ \\
\hline The skills I acquired are: & \\
\hline Online platform-related skills (e.g., skills about Blackboard) & 31.1 \\
Group-related skills (e.g., team formation) & 7.8 \\
General knowledge-related skills & 8.9 \\
Technical skills (e.g., operating systems, computer) & 16.7 \\
All or some of the above & 35.5 \\
Total & $100 \%$ \\
\hline
\end{tabular}

Do online courses appeal to students because they are, for example, easier and/or more convenient than courses offered on face-to-face basis? Is online learning more effective from students' perceptions than the traditional face-to-face education? Information contained in Table 3 provides interesting insights into students' perceptions about these issues. Based on the data in Table 3, it is difficult to conclude with certainty that, from students' viewpoints, that courses offered online are easier to successfully complete than traditional face-to-face course. Only $39.4 \%$ of the participants believed that online courses are easier than the traditional, in-campus courses, while $28.6 \%$ of them felt online courses were more difficult.

In regard to performance, $28.6 \%$ of the participants agreed to the notion that enrolling in online courses could lead to higher student performance than in face-to-face courses, while $36.7 \%$ of the respondents disagreed with the statement that it is easier to achieve better performance in online learning as compared to face-to-face learning. 
Table 3. Ease and Effectiveness of Online Learning

\begin{tabular}{lc}
\hline Do you think that the online courses are easier to complete than in-class, face-to-face courses? & Percentage \\
\hline Agree & 29.9 \\
Strongly agree & 9.5 \\
Disagree & 21.8 \\
Strongly disagree & 6.8 \\
Neutral & 32.0 \\
Total & $100 \%$ \\
\hline Do you think that it is easier to achieve better performance (e.g., higher grades) in online & 21.1 \\
courses than in face-to-face classes? & 7.5 \\
\hline Agree & 29.9 \\
Strongly agree & 6.8 \\
Disagree & 34.7 \\
Strongly disagree & $100 \%$ \\
Neutral & \\
\hline
\end{tabular}

Would the participants recommend institutions of higher education to offer more online courses? The data indicate that the majority $(61.9 \%)$ of the participants agreed that offering of more online courses is highly beneficial to students. Approximately $18 \%$ disagreed or strongly disagreed and $19.7 \%$ were neutral. Further analysis, as shown in Table 4, indicates that $49.0 \%$ of the employed students (fulltime or part time) would have enrolled in more online courses during a semester had the courses been available. On the other hand, only $30.8 \%$ of the unemployed students would have enrolled in more courses during a semester if they had been able to find more online courses.

Table 4. Employment * I would have enrolled in more courses during a semester if I were able to find more online courses

\begin{tabular}{|c|c|c|c|c|c|c|c|}
\hline & & \multicolumn{5}{|c|}{$\begin{array}{l}\text { I would have enrolled in more courses during a semester if I } \\
\text { were able to find more online courses }\end{array}$} & \multirow{2}{*}{ Total } \\
\hline & & Agree & $\begin{array}{l}\text { Strongly } \\
\text { agree }\end{array}$ & Disagree & $\begin{array}{l}\text { Strongly } \\
\text { disagree }\end{array}$ & Neutral & \\
\hline \multirow{3}{*}{ Employment } & $\begin{array}{l}\text { Employed full } \\
\text { time }\end{array}$ & 23 & 12 & 17 & 7 & 4 & 63 \\
\hline & $\begin{array}{l}\text { Employed part } \\
\text { time }\end{array}$ & 12 & 6 & 17 & 5 & 5 & 45 \\
\hline & Unemployed & 9 & 3 & 13 & 8 & 6 & 39 \\
\hline Total & & 44 & 21 & 47 & 20 & 15 & 147 \\
\hline
\end{tabular}

Are there differences in the perceptions based on gender? As shown in Table 5, further analysis indicates that there are distinct differences between males' and females' perceptions. The findings indicate $48.4 \%$ of the males think that the online courses are easier to complete than face-to-face courses, whereas only $32.9 \%$ of the female are agreed.

Table 5. Gender * Online courses are easier to complete than in class, face-to-face courses

\begin{tabular}{llllllll}
\hline & & \multicolumn{6}{l}{ Online courses are easier to complete than in-class, face-to-face courses } \\
\cline { 2 - 7 } & & Agree & $\begin{array}{l}\text { Strongly } \\
\text { agree }\end{array}$ & Disagree & $\begin{array}{l}\text { Strongly } \\
\text { disagree }\end{array}$ & Neutral & Total \\
\hline Gender & Male & 24 & 6 & 14 & 1 & 17 & 62 \\
\cline { 2 - 7 } & Female & 20 & 8 & 18 & 9 & 40 & 85 \\
\hline Total & 44 & 14 & 32 & 10 & 47 & 147 \\
\hline
\end{tabular}


Table 6 further illustrates the difference in perception based on gender. Data show $32.3 \%$ of male respondents believe that learning online is not as effective as face-to-face courses, compared to $15.3 \%$ of female respondents. On the other hand, $19.4 \%$ of male respondents believe the online learning is superior to face-to-face compared to $41.2 \%$ of female respondents.

Table 6. Gender * I believe learning online compared to face-to-face learning environment

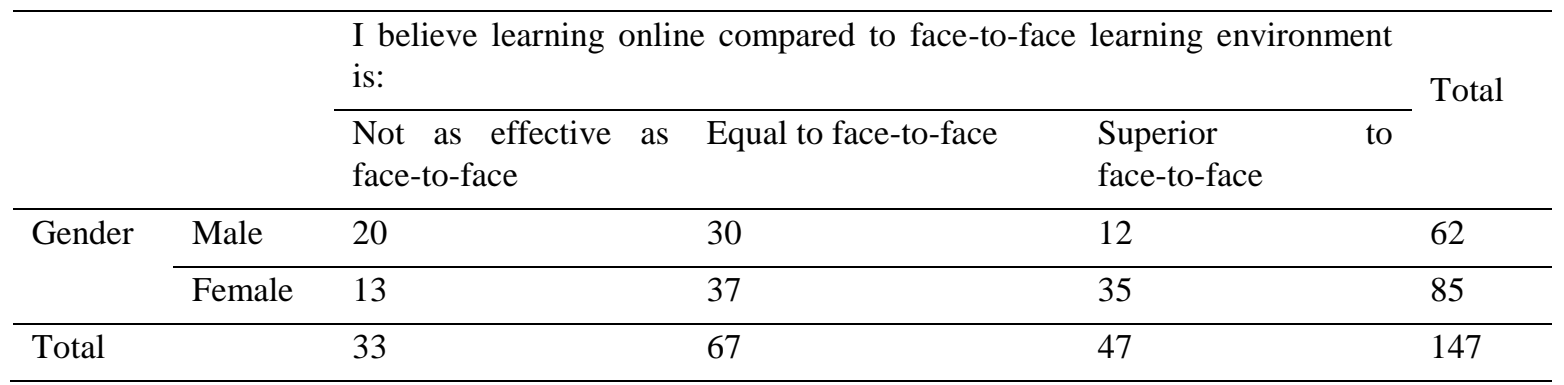

Additional analysis was performed to explore students' perceptions about the amount that they learned in an online environment compared to a similar face-to-face environment. As shown in Table 7, data indicate that $27.1 \%$ of the undergraduate students agree that they learned more in an online teaching environment than in a comparable face-to-face classroom environment, whereas only $10.4 \%$ of the graduate students are agreed.

Table 7. Education * Overall, I believe I learned more in an online teaching environment than a comparable face-to-face classroom setting

\begin{tabular}{|c|c|c|c|c|c|c|c|}
\hline & & \multicolumn{5}{|c|}{$\begin{array}{l}\text { Overall, I believe I learned more in an online teaching environment } \\
\text { than a comparable face-to-face classroom setting }\end{array}$} & \multirow{2}{*}{ Total } \\
\hline & & Agree & $\begin{array}{l}\text { Strongly } \\
\text { agree }\end{array}$ & Disagree & $\begin{array}{l}\text { Strongly } \\
\text { disagree }\end{array}$ & Neutral & \\
\hline \multirow[t]{2}{*}{ Education } & Graduate & 5 & 3 & 32 & 18 & 19 & 77 \\
\hline & Undergraduate & 14 & 5 & 25 & 11 & 15 & 70 \\
\hline Total & & 19 & 8 & 57 & 29 & 34 & 147 \\
\hline
\end{tabular}

\section{Conclusion}

Over the past decades, most institutions have expanded the list of courses being offered online and a growing number of students favor online courses over traditional face-to-face courses. This is due in part to the flexibility that online courses provide, the convenience, and a host of other factors. Respondents in this study indicated that offering more online courses would be highly advantageous to students. These findings are consistent with prior research studies (Brown 2016; Pai, 2013; Neuhauser 2010) that have examined traditional versus online education. The majority of students perceived their online experience as being positive despite multiple problems in the online courses, including lack of instructional materials, poor organization, limited faculty access and poor technological infrastructure. These findings are similar to research conducted by Allen and Seamans (2013). In addition, the majority of students found the lecture materials and assignments difficult to understand. These findings suggest that institutions need to address their students' desire for more flexible, technology-oriented educational platforms, and to exert greater efforts to eliminate obstacles that might hinder the smooth utilization of these technologies.

In education institutions around the world, the debate continues as to whether online courses are perceived as being as less rigorous than face-to-face course. Similarly, respondents in this study were almost equally divided regarding the issue of whether the online courses were easier than traditional face-to-face courses even though they found the material difficult to understand. Findings in this study also indicated males and females differ in their perceptions regarding the ease of online courses compared to traditional face-to-face or on ground courses. However, additional research is needed to fully understand why these differences exist and whether the differences can be attributed to course design, course content, faculty engagement or other factors.

\subsection{Future Research}

Future research is needed to explore the gender effects on student perceptions, if there is a relationship between those courses that are perceived as good and the amount of course design training faculty have received. More research is also needed to determine which problems (lack of instructional materials, poor organization, limited access to faculty 
or poor technological infrastructure) have the greatest effect on students and how these issues affect their perceptions of online courses. Addition research is also needed to determine why students think it is easier to achieve higher grades in online course rather than in face-to-face course and whether this perception contributes to employers' negative perceptions of online coursework.

\subsection{Contribution}

For years, much of the literature has focused on common issues and challenges affecting online course content delivery, course design and assessment within learning environments. Unfortunately, much of the research has been conducted in majority institutions and little has been conducted in minority-serving institutions. The result has been a void in the literature. This study fills this void and provides several other contributions. First, it provides educators greater insight into how some minority students within the minority-serving communities may perceive online courses versus face-to-face courses. For educators teaching in these environments, this information is very valuable. The findings in this study also bring awareness to common issues that face minority students and enables educators, administrators and course designers to better understand and reduce the likelihood of recurring problems like those identified by the students in this study. Lastly, the study provides information that can be used to address concerns that administrators and faculty have about course delivery options and how various factors including level of education, gender and employment may affect students' perceptions about traditional versus face-to-face courses.

\section{References}

Allen, I. E., \& Seaman, J. (2013). Changing Course: Ten Years of Tracking Online Education in the United States. Babsob Survey Research Group, pp. 4-5.

Allen, I.E., \& Seaman, J., (2011). Going the Distance: Online Education in the United States, 2011. Babson Survey Research Group pp. 4-5.

Banas, E., \& Emory, W. (1998). History and issues of distance learning, Public Administration Quarterly, 22(3), 365-383.

Cao, Y. (2011). Online versus traditional MBA: An empirical study of students' characteristics, course satisfaction, and overall success, The Journal of Human Resources and Adult Learning, 7(2), 1-12.

Bernard, R. M., Abrami, P. C., Lou, Y., Borokhovski, E., Wade, A., Wozney, L., \& Huang, B. (2004). How does distance education compare with classroom instruction? A meta-analysis of the empirical literature. Review of educational research, 74(3), 379-439. http://dx.doi.org/10.3102/00346543074003379

Brown, J. C., \& Park, H. S. (2016). Longitudinal student research competency: Comparing online and traditional face-to-face learning platforms. Advances in Social Work, 17(1), 44-58. http://dx.doi.org/10.18060/20870

Bhuasiri, W., Xaymoungkhoun, O., Zo, H., Rho, J. J., \& Ciganek, A. P. (2012). Critical success factors for e-learning in developing countries: A comparative analysis between ICT experts and faculty. Computers \& Education, 58(2), 843-855. http://dx.doi.org/10.1016/j.compedu.2011.10.010

Cavanaugh, J., \& Jacquemin, S. J. (2015). A large sample comparison of grade based student learning outcomes in online vs. face-to-face courses. Online Learning Journal, 19(2).

Chou, P. (2012). The relationship between engineering students' self-directed learning abilities and online learning performance: A pilot study. Contemporary Issues in Educational Research, 5(1), 33. http://dx.doi.org/10.19030/cier.v5i1.6784

Clark, R. A., \& Jones, D. (2001). A comparison of traditional and online formats in a public speaking course. Communication Education, 50(2), 109-124. http://dx.doi.org/10.1080/03634520109379238

Cowden, P., \& Sze, S. (2012, July). Online Learning: The Concept of Less Is More. In Allied Academies International Conference. Academy of Information and Management Sciences. Proceedings, 16(2), 1. Jordan Whitney Enterprises, Inc.

Deming, D. J., Goldin, C., \& Katz, L. F. (2012). The for-profit postsecondary school sector: Nimble critters or agile predators? Journal of Economic Perspectives, 26(1), 139-164. http://dx.doi.org/10.1257/jep.26.1.139

Dendir, S. (2016). An online premium? Characteristics and performance of online versus face-to-face students in Principles of Microeconomics. Journal of Education for Business, 91(2), 59-68. http://dx.doi.org/10.1080/08832323.2015.1110555 
DiRienzo, C., \& Lilly, G. (2014). Online versus face-to-face: Does delivery method matter for undergraduate business school learning? Business Education \& Accreditation, 6(1), 1-11.

Farmakis, H., \& Kaulbach, M. (2013). Teaching online? A guide on how to get started, International Journal of Organizational Innovation, 6(2), 34-40.

Fedynich, L., Bradley, K. S., \& Bradley, J. (2015). Graduate students' perceptions of online learning. Research in Higher Education Journal, 27, 1.

Ferriman, J. (2013). The History of Distance Learning (Infographic). Learn Dash, www.learndash.com/the-history-of-sistance-learning. Retrieved on July 11, 2014.

Giroux, H. (2015). Higher education and the promise of democracy. In Future of Higher Education: Perspectives from America's Academic Leaders, 53.

Harasim, L. M. (1989). Online education: A new domain. In Mason, R.D. and Kaye, A.R. (editors), Mindweave Communication, Computers, and Distance Education, Oxford, Pergamon, Press.

Hatcher, M., Henson, J., \& LaRosa, P. (2013). Determinants of success in an online management information systems course: The significance of grade point average as a performance indicator. International Journal of Business Strategy, 13(4), 129-132. http://dx.doi.org/10.18374/IJBS-13-4.7

Haughton, J., \& Kelly, A. (2015). Student performance in an introductory business statistics course: Does delivery mode matter? Journal of Education for Business, 90(1), 31-43. http://dx.doi.org/10.1080/08832323.2014.968518

John, O., Main, S., \& Cooper, M. (2014). Student perceptions of online interactive versus traditional lectures; Or how I managed not to fall asleep with my eyes open. Journal of Online Learning and Teaching, 10(3), 405.

Kartha C. P. (2006). Learning business statistics, The Business Review, Cambridge, 5(1), 27-32.

Katy, B., \& Anderson, P. (2006). Performance of distance learning students in small business management courses, Education \& Training, 48(8/9), 642-653. http://dx.doi.org/10.1108/00400910610710065

Keegan, D. J. (1980). On defining distance education. Distance education, 1(1), 13-16. http://dx.doi.org/10.1080/0158791800010102

Kim, K., Liu, S., \& Bonk, C.(2005). Online MBA students' perceptions of online learning: Benefits, challenges, suggestions, Internet and High Education, 8(4), 335-344. http://dx.doi.org/10.1016/j.iheduc.2005.09.005

Maxwell, Joseph A. Qualitative research design: An interactive approach: An interactive approach. Sage, 2012.

McCarty, C., Bennett, D., \& Carter, S. (2013). Teaching college microeconomics: Online vs. traditional classroom instruction. Journal of Instructional Pedagogies, 11(1), 20-28.

Means, B., Toyama, Y., Murphy, R., \& Jones, K. (2009). Evaluation of evidence-based practices in online learning: A meta-analysis and review of online learning studies. Washington, DC: U.S. Department of Education. Office of Planning, Evaluation and Policy. Retrieved January 29, 2015 from http://files.eric.ed.gov/fulltext/ED505824.pdf.

Miller, G. (2014). History of Distance Learning. Retrieved May 5, 2016 at: http://www.worldwidelearn.com/education-articles/history-of-distance-learning.html

Moore, M. (1990). Recent contributions to the theory of distance education. Open leaning, 5(3), 10-15. http://dx.doi.org/10.1080/0268051900050303

Murdock, J., William, A., Becker, K., Bruce, M., \& Young, S. (2012). Online versus on-campus: A comparison study of skills sources, The Journal of Human Resources and Adult Learning, 8(1), 105-118.

Neuhauser, C. (2010). Learning style and effectiveness of online and face-to-face instruction. The American Journal of Distance Education.

Oliver, M. (2000). Evaluating online teaching and learning, Information Services \& Use, 20(2/3), 83-94.

Pai, K. (2013). Assessing Online versus face-to-face learning, Proceedings, Global Conference on Business \& Finance, 8(2), 350.

Pappas, C. (2013). The History of Distance Learning-Infographic, E-learning Industry, Retrieved July 12, 2014, from www.elearningindustry.com/the-industry-of-distance-learning. 
Saad, L., Busteed, B., \& Ogisi, M. (2013), Gallop Poll Briefing, October $5^{\text {th. }}$ Retrieved May 5, 2016, from http://www.gallup.com/poll/165425/online-education-rated-best-value-option.aspx.

Sauers, D., \& Walker, R. (2004). A comparison of traditional and technology-assisted instructional methods in the business communication classes. Business Communication Quarterly, 67(4), 430-442. http://dx.doi.org/10.1177/1080569904271030

Sanford, D., Ross, D., Rosenbloom, A., Singer, D. \& Luchsinger, V. (2014). The role of business majors in student perceptions of learning and satisfaction with course format. MERLOT Journal of Online Learning and Teaching, 10(4), 535-550. Retrieved February 2, 2015 from http://jolt.merlot.org/vol10no4/Fonolahi_1214.pdf.

Schlosser, L.A., \& Simonson, M.R. (2009). Distance education: Definitions and glossary of terms. IAP, 2009.

Shotwell, M., \& Apigian, C. H. (2015). Student performance and success factors in learning business statistics in online vs. on-ground classes using a web-based assessment platform. Journal of Statistics Education, 23(1), 1-19.

Summers, J., Waigandt, A, Whittaker, T. (2005). A comparison of student achievement and satisfaction in an online versus a traditional face-to-face statistics class. Innovative Higher Education, 29(3), 233-250. http://dx.doi.org/10.1007/s10755-005-1938-x

Talebian, S., Mohammadi, H. M., \& Rezvanfar, A. (2014). Information and communication technology (ICT) in higher education: advantages, disadvantages, conveniences and limitations of applying e-learning to agricultural students in Iran. Procedia-Social and Behavioral Sciences, 152, 300-305. http://dx.doi.org/10.1016/j.sbspro.2014.09.199

The Economist (2012, December 1). What it used to be: American universities represent declining value for money to their students.

Toven-Lindsey, B., Rhoads, R. A., \& Lozano, J. B. (2015). Virtually unlimited classrooms: Pedagogical practices in massive open online courses. The internet and higher education, 24, 1-12. http://dx.doi.org/10.1016/j.iheduc.2014.07.001

Tseng, H., \& Chu, S. (2010). Traditional versus online courses: Efforts and learning performance. The Journal of Human Resources and Adult Learning, 6(1), 115-121.

U.S. Department of Education, National Center for Education Statistics. (2015). Digest of Education Statistics, 2013 (NCES 2015-011), Chapter 2. 